American Journal of Animal and Veterinary Sciences 3 (2): 57-61, 2008

ISSN 1557-4555

(C) 2008 Science Publications

\title{
First Confirmed Case of Digital Dermatitis in Greece
}

\author{
${ }^{1}$ P.D. Katsoulos, ${ }^{2}$ A. Minas and ${ }^{1}$ G. Christodoulopoulos \\ ${ }^{1}$ Clinic of Medicine, School of Veterinary Medicine, University of Thessaly, \\ P.O. Box 199, 431 00, Karditsa, Greece \\ ${ }^{2}$ Laboratory of Microbiology, Faculty of Health Professions, Technological Educational \\ Institution of Larissa, Larissa, Greece
}

\begin{abstract}
The objective of the present study was to report the first confirmed case of digital dermatitis in Greece, emphasizing to the clinical appearance of the disease and to discuss some potential mechanisms concerning the entrance and the contagiousness of the disease in a new herd. The outbreak occurred in a new dairy farm of 60 primiparous Holstein cows in Thessaloniki region. All the animals had been purchased as pregnant heifers five months before the onset of the disease and were clinically healthy without any abnormality on their limbs at their arrival in the herd. At the time of our visit a detailed clinical history was obtained and all cows of the herd were examined for lesions of digital dermatitis. Skin biopsies were taken from each affected cow for bacteriological examinations. The clinical examination revealed that 22 animals had lesions of digital dermatitis. The diagnosis was based on the typical clinical appearance of the disease and was confirmed by the detection of Treponema on the smears from biopsy materials. The majority of the animals were affected during the first 2-3 months of lactation and their mean lameness score was 2.68 . The present study reported the first confirmed case of digital dermatitis in Greece and provided evidence that the disease can be entered in a farm by clinically healthy animals but certain initiating conditions should be met in order the to have clinical manifestation of the disease.
\end{abstract}

Key words: Digital dermatitis, contagiousness, new herd, dairy cows

\section{INTRODUCTION}

Digital dermatitis is an important disease of the feet of cattle and is presented as painful, erosive ulcerations of the limb, usually located on the skin of the posterior aspect of digits, proximal to the interdigital cleft and midway between the heel bulbs ${ }^{[1,2]}$ It is regarded as a significant cause of lameness and poor welfare ${ }^{[3,4]}$, which affects the productivity of dairy cows $^{[5]}$. The disease has been reported in the most parts of the world, but, according to our knowledge, has not been described, so far, an outbreak in new established dairy herd that the only entered livestock was exclusively clinically healthy heifers. The exploration of such condition is considered important because can give useful information about the entrance and the transmission of the disease in a farm.

In Greece, digital dermatitis has not been reported yet, although a disease with similar clinical appearance is known in veterinarian practitioners since approximately 10 years ago, when the first cases were observed. The objective of the present study was to report the first confirmed case of digital dermatitis in Greece, emphasizing to its clinical appearance and to discuss some potential mechanisms concerning the entrance and the contagiousness of the disease in a new established dairy herd.

\section{MATERIALS AND METHODS}

Animals and farming conditions: The outbreak occurred in a dairy farm of Thessaloniki region consisting of 60 Holstein cows at the 1st lactation. The farm was established about 8 months before the onset of the disease and no animal was entered before in the herd. All the cows were purchased from three farms of Germany as pregnant heifers in February 2005 and calved within three months, from April to June 2005. They were housed in a free-stall barn with concrete floor covered with shades and had free access to a yard. A scraper was in use twice a day (morning and afternoon) to remove manure from the concrete floor

Corresponding Author: P.D. Katsoulos, Clinic of Medicine, School of Veterinary Medicine, University of Thessaly, P.O. Box 199, 43100 Karditsa, Greece Tel: +30 2441066056 Fax: +30 2441066055 
and a system of misters was employed for cooling during summer.

Clinical history: The disease was first detected in late July 2005. In the milking parlor the farmer observed 5 cows with a circular area with erected hair on the skin above the heels which was very painful in touch. Thereafter, all cows were closely examined by the farmer during milking for the detection of new cases. The next month, 10 more cases were appeared and two months after the onset of the disease, when we visited the farm, 22 of the 60 animals were affected. According to the herdsman, at the arrival of the cows in the herd, a clinical examination was performed by the attending veterinarian, including examination of the limbs for the detection of potential claw disorders, which revealed no abnormalities. Furthermore, nobody else had access to the farm, except the veterinarian who used the equipment of the herd and the farmers were not visiting other herds.

Clinical examination: At the time of our visit all cows of the farm were screened for lesions of digital dermatitis at the milking parlor, after washing feet with a water hose. The lesions of the caudal aspect of the foot were detected at the milking places using a flashlight, while those of the cranial aspect during the exit of the animals from the milking parlor. The lameness was scored to the affected animals according to the method described by Sprecher et al. ${ }^{[6]}$, using a scale from 1 (= normal) to 5 (= severely lame) and the cows were trimmed for the complete exposure of the lesions. For each digital dermatitis case, the cow's identification number, the month of lactation that farmer first observed the lesion at this animal, the feet involved and the type and location of the lesions were recoded. According to their type, the lesions were classified in three categories. The erosive, the early stage of the lesions, characterized by focal superficial inflammation of the skin with strawberry-like appearance, the proliferative with ulcerative appearance and wart-like structures with mated hair and the regressing (scabbed) type, the latest stage of the lesion before healing, with scab over the damaged skin. Any other lesions of the limbs, except those of digital dermatitis, were recorded as well.

Sample collection and bacteriological examination: Skin biopsies were collected, one for each type of lesion, for bacteriological examination. The biopsies were taken using sterile biopsy punches from the periphery of the lesion, after infiltration with lidocaine hydrochloride $2 \%$. Smears of the biopsies were examined, using China-ink stain and Victoria blue 4-R stain for the detection of Treponeme-like organisms and were observed microscopically x100. Furthermore, anaerobic cultures were performed on fastidious anaerobic agar with $10 \%$ horse serum added and supplemented with $100 \mu \mathrm{g} \mathrm{mL}^{-1}$ kanamycin and $7.5 \mu \mathrm{g} \mathrm{mL}^{-1}$ vancomycin, for the confinement of other bacteria.

\section{RESULTS AND DISCUSSION}

The clinical examination revealed that 22 of the 60 animals $(36.7 \%)$ of the farm were affected with digital dermatitis. The hind feet were infected in 17 of 22 cases $(77.3 \%)$, in 11 of which the infection was bilateral and the front feet in 5 cases. The lesions were very painful at palpation and were located either at the skin above the heels (17 cases, $77.3 \%$ ), or at the interdigital space (3 cases, 13.6\%), or at the dorsum (2 cases, 9.1\%). Concerning the type of the lesion, the proliferative type was observed in 10 cases $(45.5 \%)$, the erosive in 7 $(31.8 \%)$ and the regressing type in $5(22.7 \%)$.

The mean lameness score $( \pm$ S.E. $)$ of the affected cows was $2.68 \pm 0.18$. None of the cows examined had any signs of other clinical diseases or other limbs' lesions.

In all smears of skin biopsies Treponeme-like organisms were detected and the anaerobic cultures yielded mixed growths of bacteria which were subsequently identified as Dichelobacter spp.

Concerning the appearance of the disease relative to calving, in 16 of the cases $(72.7 \%)$ the lesions were manifested at the 3rd month post-partum (pp), in 5 $(22.8 \%)$ at the 2 nd month and in $1(4.5 \%)$ at the 4th month pp.

The present study provides the first evidence about the existence of digital dermatitis in dairy cows in Greece. The diagnosis of digital dermatitis at the present herd was based on the clinical signs of the disease and was confirmed by the detection of Treponeme-like organisms on the smears from biopsy materials. Although the precise aetiopathogenesis of bovine digital dermatitis has not been determined yet, treponemes are believed to have major role on the aetiology of the disease, as they have been implicated in many studies ${ }^{[7-10]}$ and, furthermore, there is evidence for anti-spirochaete $^{[9.11]}$ and anti-treponeme response in infected cows ${ }^{[10]}$, which is not seen in unaffected animals $^{[11]}$. The detection of Treponeme-like organisms at the early stages of digital dermatitis (erosive type) was very useful to differentiate this type of lesions by interdigital dermatitis as both diseases are very similar and occur at the same area of the hoof. The isolation of 
Dichelobacter spp. concurs with the findings of other studies $^{[2]}$, but these bacteria are mostly considered as secondary invaders rather than primal pathogens.

The location and the type of the lesions of the digital dermatitis recorded at the present outbreak were, in general, similar to those in former reports ${ }^{[2,4]}$ and can be characterized as typical for the disease. The mean lameness score of the affected animals was about 2.7, suggesting that the cows were mildly to moderately lame ${ }^{[7]}$. Probably, this is the reason why lameness was not the first clinical sign noticed by the farmer at the present study. In support to this finding, other researchers ${ }^{[12,13]}$ referred that lameness is not a significant finding among the affected cows.

A question that arose at the present outbreak was how the disease entered in the farm, given that these animals had no visible abnormalities on their limbs, they were the first that entered in the herd, nobody else had access to the farm and the farmers were not visiting other herds. The most possible answer is that the animals were already "carriers" of treponemes at their arrival in the farm and either they were infected, but at preclinical level, or these microorganisms existed in the gastrointestinal tract of some animals originated from infected herds and were gradually released, infecting the other cows. It is well known that treponemes make up part of the symbiotic ruminal flora ${ }^{[14-17]}$, so a gastrointestinal reservoir is a possibility. Furthermore, Shibahara et al. ${ }^{[18]}$ provided evidence to this possibility showing concurrent infections with morphologically similar spirochaetal organisms occurring in the feet and colon of cattle. However, none of the above proposed mechanisms could be proved at the present study because treponemmes or their antibodies should have been detected at the arrival of the animals.

Independently of how the treponemes entered the herd, they required appropriate animal/environmental conditions in order to develop clinical disease. These conditions were met after calving, given that the great majority of the cows ( 21 animals) were affected during the first 2-3 months of lactation, when the peak of lactation occurs. In accordance to this finding, it has been observed in former studies that cows at the peak of lactation were more susceptible to the disease ${ }^{[19]}$. A possible explanation might be that cows at the peak of lactation are generally fed a ration with high proportion of concentrates, resulting in more liquid feces and higher exposure to wet and unhygienic conditions. Furthermore, the low $\mathrm{pH}$ of the feces might cause a favorable environment for the survival of the infectious agents of digital dermatitis.
The rapid spread of the disease in the herd, within 3 months, is probably due, beyond the short calving period, which had as a result all cows of the farm to be at similar stage of lactation, to the unhygienic condition underfoot that occurred in the farm because of the improper use of the scraper. The animals, although had access to a yard, because of the high temperature, they were congregated the most time of the day on the concrete floor under the shades and the misters for coolness, which, in combination with the improper use of the scraper, increased the moisture of the floor and the cows' contact with the manure. Both concrete floor $^{[20-22]}$ and moisture ${ }^{[23]}$ are considered important risk factors for the development of the disease and the improper use of scraper has been related with the onset of a former outbreak ${ }^{[2]}$.

The high percentage of the affected animals at the present outbreak is probably related to the fact that the disease were first appeared to the herd; similar rates have been recorded in first diagnosed cases ${ }^{[2,5]}$ whereas, they are lower in endemic conditions ${ }^{[12,19,22,23]}$. A second contributive factor might be the age of the animals. It has been proved in former studies that first parity cows are at high risk for the development of digital dermatitis ${ }^{[4,19,21,23]}$ and it has been attributed to metabolic and environmental changes before and after calving and the stress associated with this event ${ }^{[4,19,21]}$.

\section{CONCLUSIONS}

The present study reported the first confirmed case of digital dermatitis in Greece and provided evidence that the disease can be transmitted in a herd even with clinically healthy animals. Of course further investigation is required in order to determine how these animals carry the treponemes and how they transmit the disease.

\section{REFERENCES}

1. Bassett, H.F., M.L. Monaghan, P. Lenhan, M.L. Doherty and M.E. Carter, 1990. Bovine digital dermatitis. Vet. Rec., 126: 164-165. $\mathrm{http} / / /$ veterinaryrecord.bvapublications.com/cgi/gc a? allch $=\&$ SEARCHID $=1 \&$ AUTHOR $1=$ bassett $\&$ FI RSTINDEX $=0 \&$ hits $=10 \&$ RESULTFORMAT $=\& \mathrm{~g}$ $\mathrm{ca}=$ vetrecord\%3B126\%2F7\%2F 164 .

2. Blowey, R.W. and M.W. Sharp, 1988. Digital dermatitis in dairy cattle. Vet. Rec., 122: 505-508. http://veterinaryrecord.bvapublications.com/cgi/gc $\mathrm{a}$ ?allch $=\&$ SEARCHID $=1 \&$ AUTHOR $1=$ blowey $\& \mathrm{~F}$ IRSTINDEX $=0 \&$ hits $=10 \&$ RESULTFORMAT $=\& \mathrm{~g}$ $\mathrm{ca}=$ vetrecord $\% 3 \mathrm{~B} 122 \% 2 \mathrm{~F} 21 \% 2 \mathrm{~F} 505$. 
3. McLennan, M. and R.A. McKenzie, 1996. Digital dermatitis in a Friesian cow. Aust. Vet. J., 74: 314-315. http://www.ava.com.au/avj/ oct96/311.htm\#Digital.

4. Read, D.H. and R.L. Walker, 1998. Papillomatous digital dermatitis (footwarts) in California dairy cattle: Clinical and gross pathology findings. J. Vet. Diagn. Invest., 10: 67-76. http://jvdi.org/ cgi/reprint $/ 10 / 1 / 67$ ? maxtoshow $=\&$ HITS $=10 \&$ hits $=$ 10\&RESULTFORMAT $=\&$ author $1=$ read $\&$ andorex actfulltext $=$ and \&searchid $=1 \&$ FIRSTINDEX $=0 \&$ so rtspec $=$ relevance $\&$ resourcetype $=$ HWCIT .

5. Argaez-Rodriguez, F., D.W. Hird, J. Hernandez de Anda, D.H. Read and A. Rodriguez-Lainz, (1997): Papillomatous digital dermatitis on a commercial dairy farm in Mexicali, Mexico: Incidence and effect on reproduction and milk production. Prev. Vet. Med., 32: 275-286. Doi: 10.1016/S01675877(97)00031-7.

6. Sprecher, D.J., D.E. Hostetler and J.B. Kaneene, 1997. A lameness scoring system that uses posture and gait to predict dairy cattle reproductive performance. Theriogenology, 47: 1179-1187. Doi: $\quad 10.1016 / \mathrm{S} 0093-691 \mathrm{X}(97) 00098-8, \quad$ URL: http://dx.doi.org/10.1016/S0093-691X(97)00098-8.

7. Demirkan, I., R.W. Blowey, R.D. Murray, S.D. Carter and M.J. Woodward, 1998. Frequent detection of treponema in bovine digital dermatitis by polymerase chain reaction and immunocytochemistry. Vet. Microbiol., 60: 285-292. .Doi: $10.1016 /$ S03781135(98)00146-1.

8. Demirkan, I., S.D. Carter, C.A. Hart and M.J. Woodward, 1999. Isolation and Cultivation of a spirochaete from bovine digital dermatitis. Vet. Rec., 145: 497-498. http://veterinaryrecord. bvapublications.com/cgi/gca?allch $=\&$ SEARCHID $=1 \&$ AUTHOR $1=$ demirkan\&FIRSTINDEX $=0$ \&hit $\mathrm{s}=10 \&$ RESULTFORMAT $=\& \mathrm{gca}=$ vetrecord $\% 3 \mathrm{~B} 1$ $45 \% 2 \mathrm{~F} 17 \% 2 \mathrm{~F} 497$.

9. Murray, R.D., D.Y. Downham, I. Demirkan and S.D. Carter, 2002. Some relationships between spirochaete infections and digital dermatitis in four UK dairy herds. Res. Vet. Sci., 73: 223-230.. Doi: 10.1016/S0034-5288(02)00027-9.

10. Dhawi, A., C.A. Hart, I. Demirkan, I.H. Davies and S.D. Carter, 2005. Bovine digital dermatitis and severe virulent ovine foot rot: A common spirochaetal pathogenesis. Vet. J., 169: 232-241. Doi: 10.1016/j.tvj1.2004.01.029.
11. Demirkan, I., R.L. Walker, R.D. Murray, R.W. Blowey and S.D. Carter, 1999. Serological evidence of spirochetal infections associated with digital dermatitis in dairy cattle. Vet. J., 157: 69-77. .Doi: 10.1053/tvjl.1998.0276.

12. Rodriguez-Lainz, A., P. Melendez-Retamal, D.W. Hird and D.H. Read, 1998. Papillomatous digital dermatitis in chilean dairies and evaluation of a screening method. Prev. Vet. Med., 37: 197-207. Doi: $10.1016 /$ S01675877(98)00091-9.

13. Milinovich, G.J., S.A. Turner, M.W. McLennan and D.J. Trott, 2003. Survey for papillomatous digital dermatitis in Australian dairy cattle. Aust. Vet. J., 82: 223-227. http://www.ava.com. au/04040223.pdf.

14. Ziolecki, A., 1979. Isolation and characterization of large treponemes from the bovine rumen. Appl. Environ. Microbiol., 37: 131-135. http://aem.asm.org/cgi/reprint/37/1/131.

15. Ziolecki, A. and M. Wojsiechowicz, 1980. Small pectinolytic spirochetes. Appl. Environ. Microbiol., 39: 919-922 http://aem.asm.org/cgi/reprint/ 39/4/919.

16. Paster, B.J. and E. Canale-Perola, 1982. Physiological diversity of rumen spirochetes. Appl. Environ. Microbiol., 43: 686-693. http://aem.asm.org/cgi/reprint/43/3/686.

17. Stanton, T.B. and E. Canale-Perola, 1979. Enumeration and selective isolation of rumen spirochetes. Appl. Environ. Microbiol., 38: 965-973. http://aem.asm.org/cgi/reprint/38/5/965.

18. Shibahara, T., T. Ohya, R. Ishii, Y. Ogihara, T. Maeda, Y. Ishicawa and K. Kadota, 2002. Concurrent spirochaetal infections of the feet and colon of cattle in Japan. Austr. Vet. J., 80: 497-502. http://www.ava.com.au/avj/0208/02080497.pdf.

19. Holzhauer, M., C. Hardenberg, C.J.M. Bartels and K. Frankena, 2006. Herd- and cow-level prevalence of digital dermatitis in The Netherlands and associated risk factors. J. Dairy Sci., 89: 580-588. http://jds.fass.org/cgi/reprint/ 89/2/580? maxtoshow $=\&$ HITS $=10 \&$ hits $=10 \&$ RES ULTFORMAT $=$ \&author $1=$ holzhauer\&andorexactf ulltext $=$ and \&searchid $=1 \&$ FIRSTINDEX $=0 \&$ sortsp ec $=$ relevance\&resourcetype $=$ HWCIT.

20. Somers, J.G.C.J., K. Frankena, E.N. NoordhuizenStassen and J.H.M. Metz, 2003. Prevalence of claw disorders in Dutch dairy cows exposed in several floor systems. J. Dairy Sci., 86: 2082-2093. http://jds.fass.org/cgi/reprint/86/6/2082?maxtosho $\mathrm{w}=\&$ HITS $=10 \& \mathrm{hits}=10 \&$ RESULTFORMAT $=\& \mathrm{au}$ thor $1=$ somers \&searchid $=1 \&$ FIRSTINDEX $=0 \&$ sort $\mathrm{spec}=$ relevance\&resourcetype $=$ HWCIT . 
21. Somers, J.G.C.J., W.G.P. Schouten, K. Frankena, E.N. Noordhuizen-Stassen and J.H.M. Metz, 2005. Development of claw traits and claw lesions in dairy cows kept on different floor systems. J. Dairy Sci., 88: 110-120 http://jds.fass.org/cgi/reprint/ $88 / 1 / 110$ ? maxtoshow $=\&$ HITS $=10 \&$ hits $=10 \&$ RES ULTFORMAT $=\&$ author $1=$ somers \&searchid $=1 \& \mathrm{~F}$ IRSTINDEX $=0 \&$ sortspec $=$ relevance \& resourcetype $=$ HWCIT.

22. Wells, S.J., L.P. Garber and B.A. Wagner, 1999. Papillomatous digital dermatitis and associated risk factors in US dairy herds. Prev. Vet. Med., 38: 11-24. Doi: 10.1016/S0167-5877(98)00132-9.
23. Rodriguez-Lainz, A., D.W. Hird, T.E. Carpenter and D.H. Read, 1996. Case control study of papillomatous digital dermatitis in southern California dairy farms. Prev. Vet. Med., 28: 117-131. Doi: 10.1016/0167-5877(96)01024-0. 